\title{
제 16차 DAC/GOVNET 전체회의
}

\section{I . 회의 개요}

제 16차 DAC/GOVENT(개도국 거버넌스 제고를 위한 DAC 네트원크) 전체회의가 2012년 4월 24 일부터 25일까지 파리 $\mathrm{OECD}$ 본부에서 개최되었다.

\section{II . 주요내용}

- 향후 거버넌스 관련 논의의 초점은 정치경제적·거시적 접근 확대, 성과 지향적 지원 및 성과측정, human right-based approach, 반부패 등이 될 것으로 전망됨.

- 수원국 책임성 제고를 위한 대안적 접근으로 의회, 시민사회, 미디어에 대한 지원이 제시됨.

- $\mathrm{OECD}$ 개발전략과의 연계방안으로 민주적 거버넌스 제고, 공공재정시스템 개선, 투자 및 인프라 관리역량 확충 등이 제안됨.

- 부산 Effective Institutions $\mathrm{BB}$ 는 수원국 시스템에 관한 논의에 정치경제적 측면을 보다 강조함과 아울러 수원국 주도의 기획, 성과관리, 역량개발, 평가의 중요성을 확산시키는데 향후 활동 초점을 맞출 예정이며 금년 중 거버넌스 관련 국제이니셔티브들이 모여 구체적 파트너십 형태 운영방안을 논의할 계획임.

\section{III. 관찰 및 평가/건의}

- 개발도상국 거버넌스 제고를 위해 현지의회, 선거제도, 시민사회에 대한 지원 필요성에 대 한 논의가 활발해 지고 있는바, 우리나라도 향후 이와 관련한 국제적 논의에 동참하기 위해 서는 동 분야에 대한 관심 및 연구 확대 필요.

- 개발원조사업의 성과평가에 대한 관심이 국제적으로 확산되어가고 있는 가운데, 가시적 성 과를 창출하는데 상대적으로 장기간이 소요되는 거버넌스 분야에서는 $\mathrm{WB}, \mathrm{UNDP}$ 등에서 성과제시 및 측정 기법 방안들을 제안하고 있으므로 우리나라의 관련 사업의 기획 및 평가 에 참고할 필요가 있을 것으로 사료됨.

- $\mathrm{OECD}$ 개발전략을 통해 개발도상국에 전수할 수 있는 거버넌스 관련 사업으로 공공재정시 스템 및 투자환경 관리 시스템 개선사업 등이 제시된 바, 동 사업들에 대한 우리나라의 참 여방안 및 모델 검토 필요. 